of scientific engineering. Engineers know that the methods of photo-elasticity-methods of experiment with which they are still for the most part unfamiliar--have already become important auxiliaries in design. Such a treatise will, I believe, be no less attractive to the physicist, to whom it will appeal in the rare moments which find him willing to turn aside from the atom and the photon to revise, and perhaps enlarge, his ideas of what happens to the 'classical 'Maxwellian waves when they traverse solid aggregates. If he discovers how to harmonise the two modes of thought, so much the better.

There is, paradoxically enough, one defect. The book is so big, so full, so thorough, that it must fail of one important purpose : it is not a textbook for the ordinary student of engineering. He needs something much more brief, direct, and simple-something that will show him the optical bench and tell him plainly how to use it. So many elementary accounts have already appeared in lectures and addresses to learned societies that the authors must be tired of that kind of exposition : but it still needs to be embodied in a handbook that will be a really handy book. Such a task is well worth doing. This excellent voluminous treatise will always be there for more advanced study and as an encyclopædia of reference: the small book, which has yet to be written, would introduce readers to it and would spread knowledge, in a way the treatise cannot be expected to do, of a subject which should be taught in every engineering laboratory, and should become, at least in its elements, part of the mental equipment of every educated engineer.

To me the book brings a personal pleasure, for it happens that both Coker and Filon were at one time my pupils. It was in the engineering laboratory at Cambridge, more than thirty years ago, that Filon carried out his earliest photo-elastic research on a loaded beam of glass. For that, however, I can claim no credit, not even the credit of suggestion. His experiments were initiated and pursued in a fine spirit of independence, a virtue only too rare among research students. Nor had I any hand in the subsequent efforts, successful and long sustained, to which this book bears witness. But even so, it gives an old teacher some satisfaction to see original work of high quality proceed from those whose early notions he may have had some small share in shaping, and to sit, as I now do, a learner at their feet.
J. A. EwING.

\title{
Albertus Magnus
}

\section{His Scientific Views}

" GVERYTHING there was to be known, he 1) knew." Thus is the genius of Albert the Great characterised by the Pope in the remarkable Bull "In Thesauris Sapientiæ" declaring the blessed Bishop of Regensburg a saint and a doctor of the Church. In this "Decretal Letter", dated Dec. 16, 1931, but published on Jan. 14, 1932, Pope Pius XI. points out that Albert the Great (1206-1280) was not only a lover of God, a pastor of souls, and a master of the sacred sciences, but also a pioneer in secular knowledge. $\mathrm{He}$ wrote about astronomy, physics, mechanics, chemistry, mineralogy, anthropology, zoology, botany, architecture, and the applied arts; and the modern edition of his writings makes thirty-eight thick quarto volumes (ed. Jammy O.P. repr. Vivès, Paris, 1890 sq.). Indeed, Albert the Great broke the chains that kept natural science in the hands of unbelievers, and vindicated it against the more timid pious persons of his time who were afraid of it for fear of its abuse. For, says the Pope, "no real theologian is afraid of any damage from the operations of nature or of natural reason rightly investigated, for these very things bear upon them the light of the Creator himself ".

We do not propose here to give any account of the edifying and active life of St. Albert the Great, or to report on the various causes which led to his canonisation by the Church. Nor do we intend to give an outline of the theological and philosophical views of a master mind who is now honoured as one of the twenty-eight doctors of the Church, together with Gregory, Basil, Ambrose, Augustine,
Jerome, Thomas Aquinas, Anselm, Bernard, Beda, Ephraem, John of the Cross, and Bellarmine. We shall endeavour, however, to give a short sketch of the scientific views of Albert the Great, which are of the greatest interest for the history of science, especially as they represent the state of scientific knowledge in the Middle Ages.

Though Albert seems to be less original and forceful as a scientific thinker than his contemporary Roger Bacon, yet he was far more influential on the age in which he lived. The peculiarity of his encyclopædic teaching was that it was based entirely on the writings of Aristotle. This was remarkable because the Aristotelian principles were resisted by the Church at the time; the provincial council at Siena in 1210 going so far as to forbid the use of Aristotle's books on natural philosophy. But though no professor was permitted to lecture on them, and in spite of the fact that in 1215 the "Physics" and the "Metaphysics" were banned by the statutes of the University of Paris, Albert the Great was actively promoting the new philosophy, probably with the connivance of the Church authorities, who allowed a responsible theologian to sift the true from the false the while they acted as the stern guardians of orthodoxy. $\mathrm{He}$ soon joined hands with his pupil Thomas Aquinas, who, if he surpassed his master in the theological and philosophical interpretations of the Stagyrite's system, does not, however, compare favourably with Albert in his scientific studies.

The astronomical beliefs of Albert, though partly No. 3251, VoL. 129] 
inspired by Aristotle, differ widely on many important points from the views of the Stagyrite. Albert taught that the heavens move from east to west carrying along with them their particular stars which move from west to east, "something like the motion of an ant on a wheel rotating in a contrary direction". The whole world is like a huge machine moved by God according to secret principles which the human intellect, however, can partly discover. Each star, in turn, is moved by a pure intellect, each having its own heavens with its particular motion; so that the circles of the stars are not concentric, as Aristotle on the authority of Eudoxus taught, but eccentric as in Ptolemy's system. Yet the earth is at the centre of the world, the heavens of the Moon, Venus, Mercury, the Sun, Mars, Jupiter, Saturn, the fixed stars, the aqueous, the crystalline and the empyreal heavens, coming in succession, the last-named being the dwelling-place of the blessed. It is this system which must have inspired Dante's cosmology; and we find in the "Paradiso" (x. 98-99) this reference to Albert the Great:

Questi, che m' è a destra piu vicino

Frate e maestro fummi, ed esso Alberto

È di Cologna.

Albert was not entirely satisfied with his cosmological theories, which are sometimes very difficult to follow (see Duhem, "Le Système du Monde", t. 3 , p. $327 \mathrm{sq}$.). He knew that his opinion could not be final when he wrote that "celestial phenomena are so far away from anything we know that we have no means of understanding them perfectly. All we know for certain is that the heavenly bodies are moved by a soul, that is, by a separate substance, an intellectual mover, a unit of intellectual life" ("De Coelo et Mundo ", 2, 13).

The belief in the existence of a pure intellect in each heavenly body led Albert to share the current opinion of his time about the influence of the stars on human beings, each intellect having a direct influence over the one immediately following it in the hierarchy of spirits. At the top of the scale, the omniscient and omnipotent mind of God controls the whole of the world, right down to the elements, the compound and the simple bodies. Parallel with this hierarchy of creatures there is a hierarchy of light and a hierarchy of weight: the four traditional elements, earth, water, air, and fire, are thus drawn up in echelons from the heaviest, earth, which is at the bottom or in the middle of things, to water, then air, and finally fire which rejoins the celestial bodies-a conception which reminds one of Anaximander's cosmogony. These considerations on the order in the realm of matter have their equivalent in the realm of spirit: the simplest intellect gives the most perfect motion to the star to which it is attached; and again, the simplest and most perfect intellect has the most adequate knowledge of things, the intrinsic and epistemological power of the various creatures being thus echeloned from the Highest God to the humblest of His creatures. The detailed development of this powerful vision of the nature of reality allows Albert the Great to state and explain his views about the various provinces of our knowledge : the part played by each natural or spiritual being is thus accounted for according to its place in the hierarchy of God's creatures.

Details about the particular sciences are interesting. In alchemy, for example, Albert himself tried several reactions, describing accurately enough the preparation of nitric acid or, as he called it, 'prime water' or philosophical water to the first degree of perfection, and giving at the same time its principal properties, such as the oxidation of metals and the separation of gold from silver. By combining three parts of prime water with one part of sal ammoniac he obtained the secondary water ; the tertiary water is obtained by treating mercury with the secondary water, and the fourth water is the result of the distillation of the tertiary water after it has been left for four days in a vessel covered with manure. This fourth water was very popular among the alchemists of the time, who called it ' philosophers' vinegar ', 'mineral water', and 'celestial dew'.

Albert distinguished four 'metallic spirits', mercury, sulphur, orpiment, and sal ammoniae, which could all be used to stain metals in gold or silver. But he warned us that the gold or the silver of the alchemists is not pure gold or silver. In fact, though the theory of a "materia prima" and the conception of transmutation made chiefly an intellectual and philosophical appeal to him, Albert did not believe in the actuality of transmutation. Thus he wrote in "De Mineralibus" (Bk, 3, 9): "Alchemy cannot change metals, but can only imitate them. I have tested alchemistic gold; but after six or seven heatings, it is burned and reduced to ashes." He was the first to use the word "affinitas", in his treatise "De Rebus Metallicis ", which was no doubt suggested to him by the views of ancient Greek philosophers current at the time, that chemical reaction is due to a similarity or kinship between the reacting substances, or, as maintained by Hippocrates, that like unites only with like. Thus, said Albert, "sulphur blackens silver and generally burns all metals, because of its natural affinity with them " (propter affinitatem naturæ metalla adurit). It seems also that Albert was the first to call sulphate of iron "vitreolum". His small treatise "De Alchimia" gives a vivid picture of the state of alchemy and alchemists in the Middle Ages, a picture which has been confirmed since by the descriptions of Paracelsus.

In his biological works Albert follows very closely Aristotle's text, given a sentence or two of the Stagyrite and adding his own remarks by way of commentary ; in sifting what is Aristotle's from Albert's additions, it has been found that the remarks of the Dominican monk contain a considerable amount of personal observations which prove that he was a naturalist of great ability. In his "Short History of Biology" (pp. 73-74), Prof. Charles Singer quotes a long passage of Albert's treatise "De Animalibus" in which there are

No. 3251, Vou. 129] 
some striking remarks about embryos of birds and of fishes; while he considers Albert's book "De Plantis " as the best work on natural history produced during the Middle Ages. Albert seems to be at a loss, however, in his attempt to draw up any general account of plants, since he reaches no satisfactory basis of classification, and is equally ignorant both of their minute structure and their true mode of reproduction. Yet his descriptions are fairly accurate, and show that he had a remarkable gift of observation.

These general remarks illustrate the range of Albert's knowledge and scientific interests. He probably wrote also on mathematics, as he often refers to his mathematical works, especially the 15th and 16th books of his geometry (iii. Met. $2,1)$; but these works have not reached us. We know, however, that Albert placed mathematics between metaphysics and natural science, the object of mathematics being defined as the motion and material extension of natural objects independently of their essence and their fundamental causes. The mathematician studies the straight line for example, as it is materially illustrated in Nature, but he does not consider the cause of the straight line or the particular matter which illus- trates it. Such considerations were possible, of course, at a time when Euclidean geometry was the only known system in terms of which Nature could be interpreted.

To-day these and the other scientific views of Albert the Great could scarcely bear the strain of a searching criticism It would be unfair, however, to dismiss Albert's claims to consideration because they do not correspond to the extraordinary developments of modern science. Should one ignore Aristotle or Plato because his biology or his cosmology is behind the present state of science? Every system of philosophy has to give some account of Nature, with reference to the scientific beliefs of the time. None of the great thinkers of the past could have possibly established his doctrines in terms of the science of the future; nevertheless, one studies them as they are and often uses them in the interpretation of modern scientific conceptions. The scientific doctrines of Albert the Great are entitled to a similar consideration; and the historian who devotes his patient efforts to the study of the "doctor universalis" will be repaid to the full by the discovery of the valuable indications contained in his writings.

\section{The Iron and Steel Industry}

$\mathrm{M}$ R. BOFFIN, it may be remembered, introduced Mr. Weg to Mrs. Boffin as "the gentleman that's a going to decline and fall off the Rooshan Empire". Prof. W. A. Bone may be introduced as the gentleman who has taken the opportunity, as Melchett medallist of the Institute of Fuel, to decline and fall off our coal and iron industry. Behind the subject he discussed, "A Century of Fuel Economy "-in (1) the manufacture of iron and steel, (2) of gas and coke and (3) in the production of power-lies the gradual decay of our iron industry. If European nations agree to disarm, if we continue to develop the use of the road engine, the interest in iron must pass over to nations like Japan and China-to the unsettled East. The topic is, therefore, one of extreme public importance.

Born in a region of coal and raised in the reek of coke-oven, gas-producer and blast-furnace, a lifelong student of the processes, Prof. Bone is a man of fuel by instinct, able to envisage and discuss the problems, both of coal and of iron, with detachment and a fullness of ripened knowledge which no other worker, either industrial or academic, has at his command. He is the recognised master artificer in the field of high temperature change, especially in gases. By his recent systematic studies of coal he has revolutionised our conception of its nature. The special department he has developed at South Kensington stands alone and unrivalled in the completeness of its equipment and the accuracy of its apposite inquiries. The Institute of Fuel could not have paid a greater compliment to the man whose memory the medal commemorates, nor have done a greater service to industrial interests, than it has in making him its medallist and so forcing him to display his knowledge of the subject, which is probably, at the moment, the most important to be considered in the whole range of industrial activity.

The story opens with the downfall, as politician, of the Duke of Wellington, in 1832, and the coincident introduction, by the Scot,.J. B. Neilson, of the hot blast, the first great step in the modern development of the iron industry, signalling the dawn of fuel economy. Neilson appears to have been a most remarkable man and a pioneer in technical education. He had intuitively guessed. that the expenditure of a given quantity of fuel (small coal) outside the furnace for the purpose of preheating the ingoing blast would save many times more fuel (coke) inside the furnace. Paradoxical though it seemed at first, trial soon proved him to be right.

The output of Scottish pig-iron rose from 37,500 tons in 1830 to 196,960 in 1839 and to 475,000 tons in 1845. Next came the utilisation of the furnace gases but not until after 1845, when the great. Bunsen and his pupil Lyon Playfair reported to the British Association the result of their analyses of the gases, taken at various levels, from a coalfired blast furnace, pointing out that $81 \cdot 54$ per cent of the fuel was lost in the form of combustible matter, only 18.46 of the whole fuel being realised in carrying out the processes in the furnace. The second invasion of the chemist into the industry was Lowthian Bell's great inquiry (1868-72) into the complex chemical interactions within the blast 